\title{
HUBUNGAN KONSENTRASI MINYAK DAN FENOL DENGAN KELIMPAHAN FITOPLANKTON DI SUNGAI ASEM BINATUR, KOTA PEKALONGAN
}

\author{
Correlation Of Oil And Phenol Concentration With The Abundance of Phytoplankton \\ in Asem Binatur River, Pekalongan City
}

Mochammad Ardiansyah, Agung Suryanto*) dan Haeruddin

Program Studi Manajemen Sumberdaya Perairan, Departemen Sumberdaya Akuatik

Fakultas Perikanan dan Ilmu Kelautan, Universitas Diponegoro

Jl. Prof. Soedarto, SH, Tembalang, Semarang, Jawa Tengah - 50275, Telp/Fax. +6224 7474698

Email : moch.ardian19@gmail.com

\begin{abstract}
ABSTRAK
Sungai Asem Binatur terletak di Kota Pekalongan, Jawa Tengah. Sungai ini selain menerima limbah domestik juga menjadi objek buangan limbah batik oleh para pelaku industri batik di daerahnya. Kandungan minyak dan fenol yang terdapat pada pembuatan batik ini mengalir menuju ke perairan sungai. Kandungan ini akan berdampak terhadap kelimpahan fitoplankton sebagai indikator kualitas perairan. Penelitian ini dilakukan pada bulan Juli - Agustus 2016 di Sungai Asem Binatur yang bertujuan untuk mengetahui konsentrasi minyak dan fenol, mengetahui kelimpahan dan struktur komunitas fitoplankton dan mengetahui hubungan antara minyak dan fenol dengan kelimpahan fitoplankton. Metode yang digunakan adalah metode survey. Teknik pengambilan sampel air di bagian tengah sungai selanjutnya dianalisis di laboratorium. Hasil penelitian menunjukkan konsentrasi minyak di lokasi penelitian berkisar antara $1,2-$ $10,4 \mathrm{mg} / \mathrm{l}$, sedangkan konsentrasi fenol berkisar antara 0,0005 - 1,167 mg/l. Kelimpahan fitoplankton berkisar antara 609 - 1649 ind/l, indeks keanekaragaman (H') dengan nilai 1,894 - 2,484, indeks dominasi (d) diperoleh nilai 0,125 0,224, dan indeks keseragaman (e) dengan nilai 0,717-0,846. Tidak terdapat hubungan yang signifikan antara minyak dengan kelimpahan fitoplankton pada taraf kepercayaan 95\% dengan nilai koefisien korelasi (r) sebesar 0,585 menunjukkan korelasi cukup. Sedangkan, terdapat hubungan yang signifikan antara fenol dengan kelimpahan fitoplankton dengan nilai korelasi (r) sebesar 0,861 menunjukkan korelasi kuat. Regresi linier berganda digunakan untuk membuktikan hubungan nyata antara minyak dan fenol dengan kelimpahan fitoplankton. Terdapat hubungan nyata dengan kelimpahan fitoplankton hanya pada konsentrasi fenol pada taraf kepercayaan 95\% dengan nilai sig = 0,022 , sedangkan konsentrasi minyak tidak terdapat hasil yang nyata sehingga dapat diabaikan dengan nilai sig $=0,809$.
\end{abstract}

Kata Kunci : Minyak; Fenol; Kelimpahan Fitoplankton; Limbah Batik; Sungai Asem Binatur.

\section{ABSTRACT}

Asem Binatur River is located in Pekalongan City, Central Java. Beside as an effluent of domestic waste, this river also an object to dump batik waste by batik industries nearby. Oil and phenol substance in these batik making flows into the river. These substance are going to cause an effect for the abundance of phytoplankton which is a water quality indicator. This research was done on July - August 2016 in Asem Binatur River and aimed to know oil and phenol substance, the abundance and phytoplankton community structure, also correlation of oil and phenol with the abundance of phytoplankton. Survey methode was used. Water sample which taken in the middle part of the river was analyzed. The result shown that oil concentration in the research location was around 1,2 - 10,4 mg/l, meanwhile phenol concentration was around 0,0005 - 1,167 mg/l. The abundance of phytoplankton was around $609-1649 \mathrm{ind} / \mathrm{l}$, diversity index ( $\left.H^{\prime}\right)$ with 1,894-2,484 value, domination index value was 0,125 - 0,224, and uniformity index (e) with 0,717-0,846 value. There is no significant relation between oil and the abundance of phytoplankton at 95\% trust level with correlation value ( $r$ ) 0,585 which is an enough correlation. Meanwhile, there is a significant correlation between phenol and the abundance of phytoplankton with correlation value (r) 0,861 which is a strong correlation. Double linier regretion was used to prove real correlation between phenol and oil with the abundance of phytoplankton. There is a real correlation with the abundance of phytoplankton but only in phenol concentration at 95\% trust level with sig value $=0,022$ while oil concentration did not have real result and could be ignored with sig value $=0,809$.

Keywords: Oil; Phenol; The Abundance of Phytoplankton; Batik Waste; Asem Binatur River.

*) Penulis penanggungjawab 


\section{PENDAHULUAN}

Pekalongan selama ini dikenal sebagai Kota Batik, karena menjadi salah satu sentra industri batik terbesar di Indonesia. Kota Pekalongan juga merupakan salah satu kota di Jawa Tengah yang memiliki jumlah Usaha Menengah, Kecil dan Mikro (UMKM) yang cukup banyak dan didominasi oleh industri garmen dan batik yaitu sekitar 90,10\% dari keseluruhan jumlah industri yang ada di Kota Pekalongan. Menurut Shujiro (2000) dalam Mratihartani (2013) jumlah industri batik skala kecil di Kota Pekalongan lebih banyak daripada kota-kota lain di Jawa Tengah, seperti tersaji dalam Tabel 1 berikut :

Tabel 1. Jumlah Industri Batik Skala Kecil Di Jawa TengahTahun 2007

\begin{tabular}{clc}
\hline No. & \multicolumn{1}{c}{ Kabupaten } & Jumlah Industri Kecil Batik \\
\hline $\mathbf{1}$ & Kota Pekalongan & $\mathbf{7 1 4}$ \\
2 & Kabupaten Pekalongan & 416 \\
3 & Kabupaten Pati & 42 \\
4 & Kabupaten Sukoharjo & 14 \\
5 & Kabupaten Surakarta & 7 \\
6 & Kabupaten Rembang & 5 \\
7 & Kabupaten Purbalingga & 3 \\
\hline & Jumlah & 1201 \\
\hline
\end{tabular}

Sumber : Disperindag Provinsi Jawa Tengah, 2007

Berdasarkan data Disperindag dan UMKM kota Pekalongan tahun 2013 tercatat ada 688 unit UKM dan 18.226 unit UKM informal dengan volume limbah cair dan proses untuk satu buah industry batik skala kecil kurang lebih 1840 liter per hari (Disperindagkop dan UMKM Kota Pekalogan, 2013).

Dalam proses pembuatan batik digunakan larutan zat kimia dengan air sebagai mediumnya dan sebagai bahan pembantu yang terdiri dari kanji, minyak, lilin, detergen dan lain-lain. Pewarnaan dan pembilasan menghasilkan air limbah yang berwana dengan bahan dari zat warna yang dipakai seperti fenol dan senyawa turunannya. Menurut Suleman (1993) dalam Setyaningsih (2006), bahwa pada umumnya limbah cair industri batik memiliki kandungan warna yang pekat, zat padat tersuspensi, BOD, COD, krom total, fenol, minyak lemak, dan $\mathrm{pH}$ yang perlu pengolahan sebelum dibuang ke badan air.

Pencemaran akibat limbah batik selayaknya wajib diperhatikan karena menimbulkan banyak dampak negatif. Berdasarkan hal tersebut maka penelitian mengenai hubungan minyak dan fenol dengan kelimpahan fitoplankton di Sungai Asem Binatur Pekalongan dilakukan dengan tujuan untuk mengetahui konsentrasi minyak dan fenol di sungai tersebut jika dibandingkan dengan baku mutu yang ada yaitu, PP No. 82 tahun 2001 tentang Pengelolaan Kualitas Air Dan Pencemaran Air. Tujuan lainnya adalah untuk mengetahui hubungan konsentrasi minyak dan fenol dengan kelimpahan fitoplankton di sungai tersebut. Penelitian ini dilakukan pada Juli - Agustus 2016.

\section{MATERI DAN METODE PENELITIAN}

\section{A. Materi Penelitian}

Materi yang digunakan dalam penelitian ini adalah air sungai. Variabel yang diamati meliputi, fitoplankton, temperatur, salinitas, arus, debit, derajat keasaman $(\mathrm{pH})$, oksigen terlarut, kecerahan dan kedalaman.

\section{B. Metode Penelitian}

\section{Metode Sampling}

Metode yang digunakan dalam penelitian ini menggunakan metode survei dengan menentukan kesamaan status ekologi dengan cara membandingkan dengan standar yang sudah ditentukan. Teknik metode survei dengan pengambilan sampel air di bagian hulu sungai berdasarkan penelitian, titik tercemar dan hulu sungai untuk selanjutnya dianalisis di laboratorium. Metode sampling dilakukan secara Purposive Sampling.

Purposive Sampling yaitu teknik pengambilan sampel yang digunakan apabila sampel yang akan diambil mempunyai pertimbangan tertentu dan kriteria khusus di setiap stasiun pengamatan. Penentuan titik pada setiap stasiun dilakukan dengan pengambilan sampel secara acak (Random). Metode tersebut adalah pengambilan sampel secara acak sederhana yang digunakan agar populasi memiliki peluang yang sama besar untuk diambil sebagai sampel dan dapat mewakili sifat dan karakteristik dari setiap stasiun (Fachrul, 2007). Setelah menentukan lokasi, tahap selanjutnya pengambilan air sampel untuk mengetahui konsentrasi minyak, fenol, kelimpahan fitoplankton dan struktur komunitas fitoplankton di Sungai Asem Binatur, Kota Pekalongan, Jawa Tengah.

\section{Analisis Statistik}

Analisis statistik menggunakan bantuan software SPSS (Statistical Package for the Social Science) vesi ke 20. Uji yang digunakan uji korelasi untuk mengetahui hubungan suatu variabel. Menurut Uyanto (2009), uji korelasi merupakan metode statistik untuk memprediksi nilai hubungan suatu variabel terikat atau prediktor (dependen,Y) berdasarkan nilai variabel bebas atau variabel respon (independen,X). Perhitungan uji statistik tersebut akan mendapatkan nilai $r$ negatif (-) menunjukan bahwa terdapat korelasi negatif atau berbanding terbalik antara kedua variabel, sedangkan untuk nilai $\mathrm{r}$ positif $(+)$ menunjukkan bahwa terdapat korelasi positif atau berbanding lurus antara kedua variabel.

Nilai koefisien korelasi (r) dapat dilihat untuk mengetahui keeratan hubungan kedua variabel. Koefisien determinasi $\left(\mathrm{R}^{2}\right)$ untuk mengetahui berapa besar nilai hubungan variabel $(\mathrm{X})$ mempengaruhi variabel (Y). Nilai signifikasi untuk 
mengetahui ada atau tidaknya signifikansi hubungan antar variabel (X) dan variabel (Y). Klasifikasi keeratan hubungan korelasi berdasarkan nilai koefisien korelasi pada tabel 2 berikut :

Tabel 2. Klasifikasi keeratan hubungan (korelasi) berdasarkan nilai $\mathrm{r}$

\begin{tabular}{lcl}
\hline No & Interval Nilai & Keeratan Hubungan \\
\hline 1 & $\mathrm{r}=0$ & Tidak ada korelasi secara linier \\
2 & $0<\mathrm{r} \leq 0.20$ & Korelasi sangat lemah \\
3 & $0.20<\mathrm{r} \leq 0.40$ & Korelasi lemah \\
4 & $0.40<\mathrm{r} \leq 0.70$ & Korelasi cukup \\
5 & $0.70<\mathrm{r} \leq 0.90$ & Korelasi kuat \\
6 & $0.90<\mathrm{r} \leq 1.00$ & Korelasi kuat sekali \\
7 & $\mathrm{r}=1.00$ & Korelasi sempurna \\
\hline
\end{tabular}

Sumber: Hasan (2003) dalam Swary (2014)

Setelah estimasi model regresi linier berganda dilakukan, maka tahap terakhir adalah menginterpretasikannya. Interpretasi atau penafsiran atau penjelasan atas suatu model yang dihasilkan seharusnya dilakukan dengan tujuan memastikan bahwa model regresi linier yang diestimasi memang layak menjelaskan pengaruh variabel bebas terhadap variabel terikat. Apabila model yang diestimasi tidak atau kurang layak, maka model tersebut memang tidak bisa digunakan untuk menafsirkan (interpretasi) pengaruh variabel bebas terhadap variabel terikat. Uji ini dilakukan dengan menggunakan rumus $\mathrm{Y}=\mathrm{a}+\mathrm{b}_{1} \mathrm{X}_{1}+\mathrm{b}_{2} \mathrm{X}_{2}$.

\section{HASIL DAN PEMBAHASAN}

Hasil

a. Gambaran Umum Lokasi Penelitian

Lokasi penelitian berada di Sungai Asem Binatur, Kelurahan Jenggot, Kecamatan Pekalongan Selatan, Kota Pekalongan, Provinsi Jawa Tengah. Penelitian ini terdapat 3 stasiun pengambilan sampel air. Secara geografis posisi koordinat lokasi pengambilan titik sampel adalah sebagai berikut :

\begin{tabular}{cc}
\hline Stasiun & \multicolumn{1}{c}{ Koordinat } \\
\hline A & $\mathrm{S}^{\circ} 55^{\prime} 36,8 \mathrm{E} 109^{\circ} 40^{\prime} 8,7$ \\
B & $\mathrm{S}^{\circ} 54^{\prime} 44,1 \mathrm{E} 109^{\circ} 40^{\prime} 4,1$ \\
C & $\mathrm{S}^{\circ} 53^{\prime} 27,8 \mathrm{E} 109^{\circ} 39^{\prime} 47,8$ \\
\hline
\end{tabular}

Sumber : Penelitian Agustus 2016

b. Konsentrasi Minyak Terlarut

Tabel 3. Hasil Konsentrasi Minyak Terlarut di Sungai Asem Binatur

\begin{tabular}{|c|c|c|c|c|c|}
\hline \multirow{2}{*}{ Analisa } & \multirow{2}{*}{ Ulangan } & \multicolumn{3}{|c|}{ Konsentrasi Minyak (mg/l) } & \multirow{2}{*}{$\begin{array}{c}\text { Baku Mutu* } \\
(\mathrm{mg} / \mathrm{l})\end{array}$} \\
\hline & & $\mathrm{A}$ & $\mathrm{B}$ & $\mathrm{C}$ & \\
\hline \multirow{3}{*}{ Minyak } & 1 & 3,2 & 3,6 & 8,8 & 1 \\
\hline & 2 & 5,2 & 10,4 & 6,4 & 1 \\
\hline & 3 & 1,2 & 2 & 3,6 & 1 \\
\hline \multicolumn{2}{|c|}{ Rataan (X) } & 3,2 & 5,3 & 6,3 & 1 \\
\hline \multicolumn{2}{|c|}{ Standar Deviasi } & 2 & 4,46 & 2,6 & 1 \\
\hline
\end{tabular}

Sumber : Penelitian Agustus 2016

*Baku Mutu Air Berdasarkan Peraturan Pemerintah No. 82 Tahun 2001

Berdasarkan data hasil pengukuran minyak di stasiun $\mathrm{A}, \mathrm{B}$, dan $\mathrm{C}$ diperoleh angka 3,2 - 8,8 mg/L pada sampling pertama, 5,2 - 10,4 mg/L pada sampling kedua, dan sampling ketiga 1,2 - 3,6 mg/L. Hasil tersebut telah melebihi baku mutu (1 mg/L) yang telah ditetapkan pada Peraturan Pemerintah No. 82 Tahun 2001 tentang Pengelolaan Kualitas Air Dan Pengendalian Pencemaran Air.

\section{c. Konsentrasi Fenol Terlarut}

Tabel 4. Hasil Konsentrasi Fenol Terlarut di Sungai Asem Binatur

\begin{tabular}{|c|c|c|c|c|c|}
\hline \multirow{2}{*}{ Analisa } & \multirow{2}{*}{ Ulangan } & \multicolumn{3}{|c|}{ Konsentrasi Fenol (mg/l) } & \multirow{2}{*}{$\begin{array}{c}\text { Baku Mutu* } \\
(\mathrm{mg} / \mathrm{l})\end{array}$} \\
\hline & & A & $\mathrm{B}$ & $\mathrm{C}$ & \\
\hline \multirow{3}{*}{ Fenol } & 1 & 0,216 & 0,605 & 0,907 & 0,001 \\
\hline & 2 & 0,389 & 0,648 & 1,167 & 0,001 \\
\hline & 3 & 0,0005 & 0,518 & 0,516 & 0,001 \\
\hline \multicolumn{2}{|c|}{ Rataan $(\mathrm{X})$} & 0,201 & 0,591 & 0,878 & 0,001 \\
\hline \multicolumn{2}{|c|}{ Standar Deviasi } & 0,195 & 0,066 & 0,303 & 0,001 \\
\hline
\end{tabular}

Sumber : Penelitian Agustus 2016

*Baku Mutu Air Berdasarkan Peraturan Pemerintah No. 82 Tahun 2001

Berdasarkan data hasil pengukuran fenol di stasiun A, B, dan C diperoleh angka 0,216 - 0,907 mg/L pada sampling pertama, 0,389-1,167 mg/L pada sampling kedua, dan sampling ketiga $0-0,518 \mathrm{mg} / \mathrm{L}$. Hasil tersebut telah melebihi 
baku mutu $(0,001 \mathrm{mg} / \mathrm{L})$ yang telah ditetapkan pada Peraturan Pemerintah No. 82 Tahun 2001 tentang Pengelolaan

Kualitas Air Dan Pengendalian Pencemaran Air.

d. Hasil Analisa Struktur Komunitas Fitoplankton

Hasil analisa struktur komunitas fitoplankton tersaji pada Tabel 5 sebagai berikut :

Tabel 5. Analisis Struktur Komunitas Fitoplankton

\begin{tabular}{cccccc}
\hline \multirow{2}{*}{ Pengulangan } & \multirow{2}{*}{ Stasiun } & $\mathrm{S}$ & Keanekaragaman & Dominasi & Keseragaman \\
\cline { 5 - 6 } & & & $\mathrm{H}^{\prime}$ & $\mathrm{D}$ & $\mathrm{e}$ \\
\hline \multirow{2}{*}{1} & $\mathrm{~A}$ & 16 & 2,094 & 0,199 & 0,755 \\
& $\mathrm{~B}$ & 13 & 2,062 & 0,179 & 0,803 \\
& $\mathrm{C}$ & 15 & 2,265 & 0,148 & 0,836 \\
\hline \multirow{2}{*}{2} & A & 12 & 2,102 & 0,159 & 0,846 \\
& B & 18 & 2,354 & 0,125 & 0,814 \\
& C & 19 & 2,403 & 0,137 & 0,816 \\
\hline & A & 19 & 2,484 & 0,126 & 0,843 \\
& B & 14 & 1,894 & 0,224 & 0,717 \\
\end{tabular}

Sumber : Penelitian Agustus 2016

Keterangan : $\mathrm{H}^{\prime}=$ Indeks Keanekaragaman $\mathrm{d}=$ Indeks Dominansi

e = Indeks Keseragaman S = Jumlah Genus

Berdasarkan hasil analisa struktur komunitas fitoplankton seperti pada Tabel 8 diperoleh jumlah genus pada masingmasing stasiun berkisar antara 12 - 19 genus dengan genus total yang ditemukan sebanyak 23 genera fitoplankton. Nilai indeks keanekaragaman (H') berkisar antara 1,894-2,484. Indeks dominasi (d) dengan nilai 0,125 - 0,224 dan indeks keseragaman (e) berkisar antara 0,717-0,846.

\section{e. Hubungan Minyak Dan Fenol Dengan Kelimpahan Fitoplankton}

Analisis korelasi digunakan untuk menganalisa hubungan antara konsentrasi minyak dan fenol dengan kelimpahan fitoplankton. Data analisis korelasi yang digunakan tersaji pada tabel berikut :

Tabel 6. Analisis Korelasi Konsentrasi Minyak dan Fenol dengan Kelimpahan Fitoplankton

\begin{tabular}{ccccc}
\hline \multirow{2}{*}{ Pengulangan } & \multirow{2}{*}{ Stasiun } & Kelimpahan & Minyak & Fenol \\
\cline { 3 - 5 } & & $(\mathbf{Y})$ & $\left(\mathbf{X}_{\mathbf{1}}\right)$ & $\left(\mathbf{X}_{\mathbf{2}}\right)$ \\
\hline \multirow{2}{*}{1} & $\mathrm{~A}$ & 878 & 3,2 & 0,216 \\
& $\mathrm{~B}$ & 1139 & 3,6 & 0,605 \\
& $\mathrm{C}$ & 1175 & 8,8 & 0,907 \\
2 & $\mathrm{~A}$ & 750 & 5,2 & 0,389 \\
& $\mathrm{~B}$ & 1451 & 10,4 & 0,648 \\
& $\mathrm{C}$ & 1649 & 6,4 & 1,167 \\
3 & $\mathrm{~A}$ & 609 & 1,2 & 0,0005 \\
& $\mathrm{~B}$ & 1054 & 2 & 0,518 \\
& $\mathrm{C}$ & 1359 & 3,6 & 0,561 \\
\hline
\end{tabular}

Sumber : Penelitian Agustus 2016

Berdasarkan tabel di atas analisis korelasi digunakan untuk mengetahui besarnya hubungan dan pengaruh variabel bebas (X) terhadap variabel tak bebas (Y). angka untuk mengetahui hubungan minyak dan fenol dengan kelimpahan fitoplankton dapat menggunakan koefisien korelasi (r) dan menggunakan koefisien determinasi $\left(\mathrm{R}^{2}\right)$. Hasil diperoleh dari analisis korelasi tersaji pada Tabel berikut :

Tabel 7. Analisis Uji Korelasi Pearson Minyak dan Fenol dengan Kelimpahan Fitoplankton

\begin{tabular}{cccc}
\hline \multirow{2}{*}{ Analisa Uji } & Korelasi & Determinasi & Signifikan $\boldsymbol{\alpha}$ \\
\cline { 2 - 4 } & $\mathbf{R}$ & $\mathbf{R}^{\mathbf{2}}$ & $\mathbf{0 , 0 5}(\mathbf{9 5 \%})$ \\
\hline Minyak & 0,585 & 0,343 & 0,098 \\
Fenol & 0,861 & 0,741 & 0,03 \\
\hline
\end{tabular}

Sumber : Uji Korelasi Pearson SPSS 20

Berdasarkan hasil pada tabel 7, maka pada taraf kepercayaan 95\% $(\alpha=0,05)$ diperoleh korelasi yang kuat antara fenol dan kelimpahan fitoplankton dengan nilai korelasi mencapai 0,861 dan nilai determinasi 0,741. Sedangkan, hasil konsentrasi minyak dengan kelimpahan fitoplankton memiliki korelasi cukup dengan nilai korelasi 0,585 dan nilai determinasi 0,343 . Kemudian dilanjutkan dengan uji regresi linier berganda dengan rumus $Y=a+b_{1} X_{1}+b_{2} X_{2}$ dengan hasil pada tabel berikut :

Tabel 8. Hasil Uji Analisis Regresi Linier Berganda 


\begin{tabular}{|c|c|c|c|c|c|c|}
\hline & \multirow{2}{*}{ Model } & \multicolumn{2}{|c|}{ Unstandardized Coefficients } & \multirow{2}{*}{$\begin{array}{c}\begin{array}{c}\text { Standardized } \\
\text { Coefficients }\end{array} \\
\text { Beta }\end{array}$} & \multirow[t]{2}{*}{$\mathrm{t}$} & \multirow[t]{2}{*}{ Sig. } \\
\hline & & B & Std. Error & & & \\
\hline \multirow{3}{*}{1} & (Constant) & 638.333 & 139.934 & & 4.562 & .004 \\
\hline & fenol & 796.535 & 259.583 & .818 & 3.069 & .022 \\
\hline & minyak & 7.378 & 29.166 & .067 & .253 & .809 \\
\hline
\end{tabular}

Sumber : Uji Regresi Linier Berganda SPSS 20

Berdasarkan Tabel 8, Hasil Uji Analisis Regresi Linier Berganda menggunakan signifikansi dengan taraf kepercayaan 95\% $(\alpha=0,05)$, maka model (persamaan) regresi linier berganda dapat diestimasi sebagai berikut :

Kelimpahan $=638,333+796,535$ fenol $+7,378$ minyak

Artinya, dengan kelimpahan fitoplankton sebanyak 638,333 ind/L dipengaruhi oleh konsentrasi fenol sebesar 796,535 $\mathrm{mg} / \mathrm{L}$, sedangkan kelimpahan hanya dipengaruhi konsentrasi minyak sebesar 7,378 mg/L. Dari kedua variabel independen (minyak dan fenol) yang dimasukkan dalam model ternyata hanya satu variabel (fenol) yang signifikan terhadap kelimpahan pada $\alpha=5 \%$. Hal ini terlihat dari probabilitas signifikansi fenol yang jauh di bawah 0,05 , yaitu 0,022. Nilai signifikansi minyak jauh berada di atas taraf kepercayaan 0,05 yaitu 0,809 , maka nilai konsentrasi minyak terhadap kelimpahan fitoplankton dalam hal ini dapat diabaikan.

\section{f. Parameter Fisika Kimia Perairan}

Parameter fisika kimia perairan merupakan faktor pendukung kehidupan fitoplankton dan persebaran minyak dan fenol, nilai rata-rata parameter fisika kimia saat sampling tersaji pada tabel berikut :

Tabel 9. Rata-Rata Hasil Pengukuran Parameter Fisika Dan Kimia

\begin{tabular}{|c|c|c|c|c|c|c|c|c|c|c|}
\hline \multirow{2}{*}{ No } & \multirow{2}{*}{ Variabel } & \multicolumn{3}{|c|}{ Stasiun A } & \multicolumn{3}{|c|}{ Stasiun B } & \multicolumn{3}{|c|}{ Stasiun C } \\
\hline & & A1 & A2 & $\mathbf{A 3}$ & B1 & B2 & B3 & $\mathrm{C1}$ & $\mathrm{C2}$ & $\mathbf{C 3}$ \\
\hline 1 & Kedalaman $(\mathrm{cm})$ & 35 & 143 & 63 & 28 & 38 & 20 & 18 & 25 & 21 \\
\hline 2 & Kecerahan $(\mathrm{cm})$ & 18 & 20 & 19 & 4 & 15 & 4 & $\sim$ & $\sim$ & $\sim$ \\
\hline 3 & Temperatur $\left({ }^{\circ} \mathrm{C}\right)$ & & 27 & & & 30 & & & 32 & \\
\hline 4 & Arus (m/s) & 0.046 & 0,093 & 0,070 & 0,183 & 0,216 & 0,135 & 0,203 & 0,233 & 0,183 \\
\hline 5 & $\operatorname{Debit}\left(\mathrm{m}^{3} / \mathrm{s}\right)$ & & 0,941 & & & 0,365 & & & 0,298 & \\
\hline 6 & $\mathrm{pH}$ & & 6 & & & 6 & & & 6 & \\
\hline 7 & Salinitas $(\% 00)$ & & 0 & & & 0 & & & 0 & \\
\hline 8 & DO (mg/l) & & 3,53 & & & 2,2 & & & 2,2 & \\
\hline
\end{tabular}

Sumber : Penelitian Agustus 2016

Berdasarkan rata-rata hasil pengukuran parameter fisika dan kimia Tabel 9 didapatkan untuk angka kedalaman sungai di ketiga stasiun berkisar antara $18-143 \mathrm{~cm}$, kecerahan berkisar antara $4-20 \mathrm{~cm}$ sampai tidak terhingga. Kecepatan arus berkisar antara $0,046-0,233 \mathrm{~m} / \mathrm{s}$, temperatur air berkisar antara $27-32{ }^{\circ} \mathrm{C}$, pH di ketiga stasiun sebesar 6. Salinitas bernilai 0 yang berarti kondisi perairan merupakan air tawar. Oksigen terlarut berkisar antara $2,2-$ $3,53 \mathrm{mg} / \mathrm{L}$ dan debit sungai dengan angka $0,298-0,941 \mathrm{~m}^{3} / \mathrm{s}$.

\section{Pembahasan}

\section{Kandungan Minyak dan Fenol}

Kandungan minyak pada limbah batik dihasilkan dari malam yang telah dilelehkan pada salah satu proses pembuatan batik. Konsentrasi minyak yang tinggi pada lokasi penelitian berkisar antara 1,2 - 10,4 mg/l, selain diperoleh dari sumber pencemar, diduga juga berasal dari sedimen. Menurut Mukhtasor (2008), Hal ini dikarenakan minyak tersebut digerakkan oleh pergerakan angin, gelombang dan arus, selain gaya gravitasi dan tegangan permukaan. Beberapa hidrokarbon minyak bersifat mudah menguap, dan cepat menguap. Proses penyebaran minyak akan menyebarkan lapisan menjadi tipis serta tingkat penguapan meningkat. Hilangnya sebagian material yang mudah menguap tersebut membuat minyak lebih padat/ berat dan membuatnya tenggelam.

Berdasarkan hasil pengamatan pada penelitian ini maka dapat dilihat bahwa konsentrasi minyak memiliki hubungan yang lemah dengan fitoplankton karena reaksi konsentrasi ini tidak bersinggungan langsung dengan perairan dan diduga kandungan minyak mengendap di dasar perairan. Konsentrasi minyak akan mempengaruhi fitoplankton apabila keberadaannya berinteraksi secara langsung dengan perairan maupun fitoplankton itu sendiri, seperti membentuk lapisan minyak yang akan menghalangi penetrasi cahaya yang dibutuhkan fitoplankton untuk melakukan fotosintesis. Selain itu, reaksi kandungan minyak lain yang mempengaruhi langsung keberadaan fitoplankton yaitu apabila dicerna langsung oleh fitoplankton.

Hasil pengujian kandungan fenol terlarut dalam air pada penelitian ini ada pada angka 0,0005 - 1,167 mg/l. Konsentrasi fenol yang tinggi diduga diperoleh dari pewarna limbah batik yang dibuang ke sungai. Menurut Sunarto 
(2004), fenol yang terdapat dalam limbah cair batik sendiri berasal dari pelorodan malam yang menempel pada kain. Selain dari limbah batik fenol berasal dari limbah domestik. Hal ini diperkuat oleh Effendi (2003), senyawa fenol $\left(\mathrm{C}_{6} \mathrm{H}_{5} \mathrm{OH}\right)$ dihasilkan dari proses pemurnian minyak, industri kimia, tekstil, plastik dan sebagainya.

\section{Hubungan Minyak dan Fenol Dengan Kelimpahan Fitoplankton}

Hasil analisis korelasi minyak dan fenol terhadap kelimpahan fitoplankton menggunakan taraf kepercayaan $95 \%$ $(\alpha=0,05)$ diperoleh nilai koefisien relasi $(\mathrm{R})$ sebesar 0,585 untuk minyak. Angka koefisien determinasi $\left(\mathrm{R}^{2}\right)$ sebesar 0,343 angka ini menunjukkan 34\% kelimpahan fitoplankton dipengaruhi oleh minyak. Signifikasi sebesar 0,098 lebih besar dari $\alpha=0.05$ dapat disimpulkan bahwa konsentrasi minyak memiliki hubungan yang lemah dengan kelimpahan fitoplankton. Hal ini didukung oleh hasil penelitian Ndraha (2010) mengenai Pengaruh Tumpahan Minyak Terhadap Plankton yang menunjukkan bahwa minyak tidak mempengaruhi komunitas plankton karena siklus hidup plankton yang relatif pendek. Selain itu, menurut Howart (1989) dalam Zulfiady (2013), bahwa dampak minyak terhadap fitoplankton dapat mematikan atau mengurangi laju fotosintesis dan pertumbuhan fitoplankton (kelimpahan berkurang), akan tetapi pada konsentrasi tertentu minyak dapat merangsang pertumbuhan fitoplankton sehingga dampak minyak akan menjadi sulit diidentifikasi.

Sedangkan hasil uji analisis korelasi fenol terhadap kelimpahan fitoplankton diperoleh angka koefisien korelasi (R) sebesar 0,861. Angka koefisien determinasi $\left(\mathrm{R}^{2}\right)$ sebesar 0,741 menunjukkan sebesar $74 \%$ kelimpahan fitoplankton dipengaruhi oleh fenol. Signifikansi sebesar 0,003 lebih kecil dari $\alpha=0.05$ dapat disimpulkan bahwa konsentrasi fenol memiliki hubungan yang kuat dengan kelimpahan fitoplankton. Menurut Qadeer \& Rehan (1998) dalam Dewilda (2012) Fenol merupakan senyawa yang dapat menimbulkan bau tidak sedap $\left(\mathrm{NH}_{3}\right.$ atau amoniak), bersifat racun dan korosif terhadap kulit (iritasi), menyebabkan gangguan kesehatan manusia dan kematian pada organisme yang terdapat pada air dengan nilai konsentrasi tertentu.

Hasil pengamatan pada tiap stasiun kelimpahan fitoplankton menunjukkan bahwa Oscillatoria merupakan genus yang banyak muncul dalam pengamatan. Hal ini menunjukkan meskipun dalam kondisi perairan yang tercemar (mengandung fenol dan minyak melebihi baku mutu) jenis fitoplankton ini dapat bertahan hidup. Hal ini sesuai dengan pernyataan Palmer (1969) dalam Riswanda (2014), bahwa Oscillatoria merupakan salah satu genus alga yang sangat toleran terhadap polutan dan dua species dari genus ini yang paling toleran terhadap polutan yaitu Oscillatoria limosa dan Oscillatoria tennis.

Senyawa fenol yang biasa digunakan untuk pewarnaan pada industri tekstil dalam hal ini pewarnaan batik adalah naphtol, naphtol sendiri memiliki ikatan rangkap dua Nitrogen $(-\mathrm{N}=\mathrm{N}-)$. Nitrogen dalam air limbah pada umumnya terdapat dalam bentuk organik dan oleh bakteri diubah menjadi ammonia. Dalam kondisi aerobik dan dalam waktu tertentu bakteri dapat mengoksidasi ammonia menjadi nitrit dan nitrat. Kemudian saat oksigen terlarut di perairan rendah maka akan mempengaruhi kegiatan mikroorganisme dalam proses dekomposisi bahan organik. Salah satunya terjadi proses denitrifikasi yaitu proses mikrobiologi dimana ion nitrat dan nitrit diubah menjadi molekul nitrogen $\left(\mathrm{N}_{2}\right)$. Kondisi inilah yang diduga mampu membuat Oscillatoria mampu bertahan hidup dengan kondisi lingkungan perairan yang tercemar. Menurut Sprent (1990) dalam Riswanda (2014) bahwa Oscillatoria merupakan organisme yang menggunakan fotosintesis sehingga membutuhkan cahaya untuk bertahan hidup dan reproduksi. Oscilatoria merupakan salah satu genus dari Cyanobacteria yang mampu menangkap $\mathrm{N}_{2}, \mathrm{~N}_{2}$ yang ditangkap dari udara akan segera direduksi dan dihasilkan menjadi $\mathrm{NH}_{3}^{+}$.

Selain genus Oscillatoria menjadi yang paling dominan dibandingkan dengan genus lain terdapat beberapa genus yang sering muncul hampir di setiap lokasi dan pengulangan, diantaranya seperti Trichodesmium sp., Nitzschia sp., Rhizosolenia sp., Bidulphia sp. dan Melosira sp. Hal ini diduga dikarenakan pada setiap pengulangan mengalami perlakuan yang sama mulai dari metode dan waktu pengambilan sampel hingga cuaca yang relatif sama sehingga memungkinkan air sampel memiliki kecenderungan kualitas yang hampir sama. Menurut Musthafa (2013), bahan organik dan anorganik yang terakumulasi pada perairan menghalangi sinar matahari untuk menembus ke dalam perairan secara sempurna sehingga menghambat proses fotosintesis alga. Alga yang hidup di perairan yang tingkat pencemarannya ringan sampai sedang ( $\beta$-Mesosaprobik) ini divisi Chrysophyta diantaranya Melosira sp., dan Spyrogira sp. Perairan yang tercemar sedang sampai berat ( $\alpha$-Mesosaprobik) dimana alga yang berperan sebagai indikator seperti Rhizosolenia sp., Nitzschia sp., dan Oscillatoria sp. Sedangkan alga sebagai indikator pencemaran perairan dari Kelas Cyanophyceae seperti Spirulina sp. dan Oscillatoria sp.

\section{Parameter Fisika Kimia Perairan}

Berdasarkan hasil rata-rata yang diperoleh, temperatur perairan di lokasi penelitian berkisar antara $27-32^{\circ} \mathrm{C}$. Temperatur air di lokasi penelitian dapat mendukung proses fotosintesis dan mempengaruhi distribusi kelimpahan fitoplankton serta oksigen terlarut. Fenol bersifat lebih asam bila dibandingkan dengan alkohol, tetapi lebih basa daripada asam karbonat karena fenol dapat melepaskan ion $\mathrm{H}^{+}$dari gugus hidroksilnya. Lepasnya ion $\mathrm{H}^{+}$menjadikan anion fenoksida $\mathrm{C}_{6} \mathrm{H}_{5} \mathrm{O}^{-}$dapat melarut dalam air. Fenol mempunyai titik leleh $41^{\circ} \mathrm{C}$ dan titik didih $181^{\circ} \mathrm{C}$. Fenol memiliki kelarutan yang terbatas dalam air yaitu $8,3 \mathrm{gram} / 100 \mathrm{~mL}$ (Fessenden dan Fessenden, 1992). Menurut Effendi (2003), kisaran temperatur optimum bagi pertumbuhan fitoplankton di perairan adalah $20-30^{\circ} \mathrm{C}$.

Cuaca di lokasi penelitian berpengaruh besar terhadap temperatur air, karena cahaya matahari yang terhalang oleh banyak pepohonan dapat menurunkan temperatur perairan. Kecerahan perairan merupakan parameter penting yang mempengaruhi kelimpahan fitoplankton. Cahaya matahari yang masuk ke dalam perairan dimanfaatkan fitoplankton 
untuk proses fotosintesis. Hal ini sesuai dengan pernyataan Fachrul (2007) bahwa semakin dalam penetrasi cahaya ke dalam perairan menyebabkan semakin besar daerah dimana proses fotosintesis dapat berlangsung.

Pengaruh arus dapat berdampak terhadap kelimpahan fitoplankton baik secara langsung dan tidak langsung. Arus dapat mempengaruhi kelimpahan fitoplankton secara langsung karena fitoplankton termasuk organisme pasif yang pergerakan dan distribusinya dipengaruhi oleh arus. Hasil yang didapat pada rata-rata keseluruhan stasiun berkisar antara $0,046-0,233 \mathrm{~m} / \mathrm{s}$. Arus yang mengalir di Sungai Asem Binatur pada setiap stasiun menjadi salah satu faktor kelimpahan dan keanekaragaman fitoplankton tinggi. Menurut Effendi (2003), kecepatan arus di perairan relatif tinggi, bahkan bisa mencapai $6 \mathrm{~m} /$ detik. Umumnya kecepatan arus berkisar pada angka $3 \mathrm{~m} / \mathrm{det}$.

Oksigen terlarut atau sering dikenal dengan DO (Dissolved Oxygen) merupakan parameter kimia perairan lainnya yang dapat mempengaruhi fitoplankton. Salah satu sumber oksigen di perairan adalah fitoplankton yang merupakan hasil akhir dari proses fotosintesis. Berdasarkan data yang diperoleh rata-rata hasil DO pada keseluruhan stasiun berkisar antara 2,2 - 3,53 mg/l. stasiun A memiliki DO yang tinggi karena kondisi perairan yang diduga belum tercemar oleh limbah batik seperti pada stasiun B dan C. Selain itu faktor kecerahan juga memberi pengaruh dimana stasiun A dan B masih dikelilingi pepohonan sedangkan pada stasiun C tidak. Menurut Boyd (1990) dalam Pirzan (2011), jika tidak ada senyawa beracun konsentrasi oksigen minimal $2 \mathrm{mg} / \mathrm{L}$ sudah cukup untuk mendukung kehidupan jasad perairan secara normal. Menurut Arisandi (2002) dalam Heltina (2008), fenol yang dibuang ke sungai dapat diuraikan oleh mikroorganisme. Namun penguraian tersebut membutuhkan oksigen terlarut yang lebih besar daripada jumlah oksigen yang dihasilkan dari proses fotosintesis

\section{KESIMPULAN}

Kesimpulan yang diperoleh dari kegiatan penelitian ini adalah sebagai berikut :

1. Angka konsentrasi minyak pada keseluruhan sampling berkisar antara 1,2 - 10,4 mg/l, sedangkan angka konsentrasi fenol pada keseluruhan sampling berkisar antara $0,0005-1,167 \mathrm{mg} / \mathrm{l}$.

2. Kelimpahan fitoplankton di Sungai Asem Binatur pada keseluruhan sampling berkisar antara $609-1649$ ind/1. Indeks keanekaragaman (H') fitoplankton pada keseluruhan sampling diperoleh angka 1,894-2,484. Hal ini menunjukkan bahwa stabilitas biota dalam tingkatan sedang. Indeks dominasi (d) diperoleh hasil dengan angka $0,125-0,224$ menggambarkan bahwa tidak terdapat genus yang mendominasi dan indeks keseragaman (e) dengan angka $0,717-0,846$ hal ini menggambarkan kemerataan masing-masing genus relatif sama.

3. Tidak ada hubungan yang signifikan antara minyak dan kelimpahan fitoplankton dengan taraf kepercayaan $95 \%$, angka koefisien relasi (r) sebesar 0,585 menunjukkan korelasi cukup. Sedangkan, angka koefisien relasi (r) sebesar 0,861 , menunjukkan terdapat korelasi kuat antara fenol dengan kelimpahan fitoplankton pada taraf kepercayaan $95 \%$. Regresi linier berganda digunakan untuk membuktikan hubungan nyata antara minyak dan fenol dengan kelimpahan fitoplankton. Pada taraf kepercayaan 95\%, terdapat hubungan nyata dengan kelimpahan fitoplankton hanya pada konsentrasi fenol dengan nilai sig $=0,022$, sedangkan konsentrasi minyak tidak terdapat hasil nyata sehingga dapat diabaikan dengan nilai sig $=0,809$.

\section{DAFTAR PUSTAKA}

Dewilda, Y., R. Afrianita dan F. Fadhillah. 2012. Degradasi Senyawa Fenol Oleh Mikroorganisme Laut. Jurnal Teknik Lingkungan. Universitas Andalas. Vol $1: 59-73$.

Effendi, H. 2003. Telaah Kualitas Air bagi Pengelolaan Sumber Daya dan Lingkungan Perairan. Kanisius, Yogyakarta.

Fachrul, M. F. 2007. Metode Sampling Bioekologi. PT Bumi Aksara, Jakarta, 198 hlm.

Fessenden, R. J and Fessenden, J. S. (1992), Kimia Organik, Jilid 2, Edisi ketiga, Penerbit Erlangga, Jakarta.

Mratihartini, A.S. 2013. Menuju Pengelolaan Sungai Bersih Di Kawasan Industri Batik Yang Padat Limbah Cair. Jurusan IESP FEB Universitas Diponegoro. Semarang.

Mukhtasor. 2008. Pencemaran Pesisir Dan Lautan. Jakarta : Padnya Paramita.

Musthafa, H. 2013. Kemelimpahan dan Keanekaragaman Jenis Plankton di Sub DAS Gajahwong, Yogyakarta. Skripsi. Yogyakarta : Fakultas Sains dan Teknologi UIN Sunan Kalijaga.

Ndraha G. 2010. Pengaruh Tumpahan Minyak Mentah (Crude oil) Terhadap Komunitas Plankton Dan Makrozoobentos Di Muara Karangsong Kabupaten Indramayu. Skripsi. Fakultas Perikanan Dan Ilmu Kelautan. Universitas Padjadjaran. Bandung.

Peraturan Pemerintah No. 82 Tahun 2001 Tentang Pengelolaan Kualitas Air Dan Pengendalian Pencemaran Air

Pirzan, A.M. dan P.R. Pong-masak. 2008. Hubungan Keragaman Fitoplankton dengan Kualitas Air di Pulau Bauluang, Kabupaten Takalar, Sulawesi Selatan. Jurusan Biologi FMIPA UNS. Surakarta. Jurnal Biodiversitas Vol 9: (3). 
Riswanda, F.S., E. Setiadi dan A. Slamet. 2014. Studi Perubahan Nilai Indeks Pencemar Badan Air Di Kota Surabaya Terhadap Dominasi, Diversitas Genus Alga Dan Konsentrasi Klorofil-a. Jurnal Teknik Lingkungan. Institut Teknologi Sepuluh Nopember. Surabaya.

Setyaningsih, H. 2006. Pengolahan Limbah Batik dengan Proses Kimia dan Adsorpsi Karbon Aktif. Tesis. Jakarta: Program Pascasarjana Universitas Indonesia.

Sunarto. 2004. Efisiensi Pemanfaatan Energi Cahaya Matahari Oleh Fitoplankton Dalam Proses Fotosintesis. Fakultaas Peternakan Dan Pertanian. Universitas Padjajaran. Jurnal Akuatika Vol.2 No.2

Swary, A. S. Hutabarat dan Haeruddin. 2014. Studi Pengaruhnya Deterjen terhadap Komposisi dan Kelimpahan Fitoplankton di Sungai Banjir Kanal Timur Semarang. Diponegoro Journal of Management Aquatic Resources. Vol. 3 (2) hal $157-165$.

Uyanto, S.S. 2009. Pedoman Analisa Data dengan SPSS Edisi 3. Graha Ilmu, Yogyakarta, 284 hlm.

Zulfiady, W, Masjamir dan Zahidah. 2013. Pengaruh Tumpahan Minyak Terhadap Distribusi Spasial Fitoplankton Di Pantai Balongan Indramayu. Skripsi. Universitas Padjajaran. Bandung. 